\title{
Minimal Chronic Hyperglycemia Is a Critical Determinant of Impaired Insulin Secretion after an Incomplete Pancreatectomy
}

\author{
J. L. Leahy, S. Bonner-Weir, and G. C. Weir \\ Research Division, Joslin Diabetes Center, and Departments of Medicine, New England Deaconess Hospital \\ and Brigham and Women's Hospital, Harvard Medical School, Boston, Massachusetts
}

\begin{abstract}
We now describe experiments that allow one to determine the consequences of $B$ cell reduction alone vs. those that result from superimposed mild hyperglycemia. Male CD rats underwent a $60 \%$ pancreatectomy (Px); controls were sham operated. 1 wk later, either $10 \%$ sucrose (SUC) was substituted as fluid supply or tap water was continued (WAT).

Plasma glucose and insulin values in Px-WAT remained equal to the sham groups; in PX-SUC the values were euglycemic for $25 \mathrm{~d}$, but then nonfasting plasma glucose rose 15 $\mathrm{mg} / \mathrm{dl}$. After 6 wk, B cell mass in Px-WAT was reduced by $45 \%$ and non-B cell mass by $57 \%$. In contrast, in Px-SUC both masses were comparable to the sham groups. The insulin response to $27.7 \mathrm{mM}$ glucose was measured using the in vitro perfused pancreas. The responses were reduced in Px-WAT but in proportion to their reduced B cell mass; in contrast, it was $75 \%$ less than expected in Px-SUC. Also, the response to arginine given at $16.7 \mathrm{mM}$ glucose was reduced only in Px-SUC.

These results show that a lowering of $B$ cell mass that does not result in hyperglycemia has no adverse effect on the remaining B cells. On the other hand, if even mild hyperglycemia develops, B cell function becomes impaired and results in inappropriately reduced insulin stores and insulin responses to marked stimuli.
\end{abstract}

\section{Introduction}

Considerable evidence is now available showing that a reduction in B cell mass of sufficient magnitude to cause hyperglycemia is inevitably followed by secretory abnormalities in the remaining B cells (1). We have proposed that chronic exposure to the elevated glucose level is what causes their development (recently referred to as the "glucose toxicity" hypothesis), and we have demonstrated similar defects in normal rats made markedly hyperglycemic for $48 \mathrm{~h}$ with in vivo glucose infusions (2). On the other hand, the effects of reduced B cell mass alone are not known.

It has been hypothesized that chronic hyperglycemia is responsible for the secretory abnormalities in non-insulin-dependent diabetes mellitus $(3,4)$, but if this is correct, then barely detectable increases in plasma glucose must be suffi-

Address all correspondence to Dr. Jack Leahy, Research Division, Joslin Diabetes Center, One Joslin Place, Boston, MA 02215.

Received for publication 24 August 1987 and in revised form 30 November 1987.

J. Clin. Invest.

(c) The American Society for Clinical Investigation, Inc. 0021-9738/88/05/1407/08 $\$ 2.00$

Volume 81, May 1988, 1407-1414 cient to cause B cell dysfunction since the early insulin response to an intravenous glucose challenge is already lost in patients with impaired glucose tolerance $(5,6)$. However, an attempt to demonstrate such an effect experimentally, by making normal rats only mildly hyperglycemic for $48 \mathrm{~h}$ with in vivo glucose infusions, was not successful (2). One explanation could be that it may take longer for secretory defects to develop with such a small degree of hyperglycemia.

The aim of this study was to determine if B cell secretory function is altered in any way after a reduction in B cell mass of insufficient magnitude to cause hyperglycemia, and then to assess whether superimposing very mild hyperglycemia has any further effect.

\section{Methods}

$60 \%$ pancreatectomy $(P x) .^{1}$ 5-wk-old male $C D$ rats weighing $90-100 \mathrm{~g}$ (Charles River Breeding Laboratories, Inc., Wilmington, MA) were anesthetized with $100 \mathrm{mg} / \mathrm{kg}$ i.p. amobarbital sodium and ether if needed. A midline abdominal incision was made and the splenic lobe of the pancreas mobilized by partially breaking mesenteric connections to the stomach, small bowel, and retroperitoneum. Pancreatic tissue was removed according to the method of Foglia (7) (as modified by Bonner-Weir et al. [8]) by gentle abrasion with cotton applicators, being careful to leave major blood vessels intact. The excised portion was bordered by the spleen and stomach extending to but not including the small flap of pancreas attached to the pylorus; it constituted $57 \pm 3 \%$ of total pancreatic weight $(n=3)$. Control rats (shams) underwent laparotomy and mobilization of the pancreas with gentle rubbing of it between the fingers. Postoperatively, all rats received standard laboratory chow and tap water ad lib.

1 wk after surgery, $10 \%$ sucrose (SUC) was substituted as the drinking solution in half the rats for either 4 or $6 \mathrm{wk}$; the others continued to receive tap water (WAT). Bottles were filled every other day after recording the volume ingested. Body weight and nonfasting plasma glucose and insulin values were measured every 7-10 $d$ in blood obtained by tail snipping. Insulin secretion was studied at the end of the 4- or 6-wk period with the in vitro isolated perfused pancreas using one of the protocols shown in Figs. 2-5. In another series of rats, $B$ and non-B cell masses were measured at the end of 6 wk.

In vitro isolated perfused pancreas. This technique has been described previously (9). Animals were anesthetized with $100 \mathrm{mg} / \mathrm{kg}$ i.p. amobarbital sodium. The perfusate was a modified KRB buffer which contained 4\% dextran (D-4751; Sigma Chemical Co., St. Louis, MO), 2 $\mathrm{mM}$ calcium, $1.2 \mathrm{mM}$ magnesium, and $0.2 \%$ BSA fraction V (Sigma Chemical Co.). It was bubbled for 20 min with $95 \% \mathrm{O}_{2}$ and $5 \% \mathrm{CO}_{2}$, and then glucose was added and the $\mathrm{pH}$ adjusted to 7.4. It was placed in a reservoir maintained at $38^{\circ} \mathrm{C}$ by water bath; $10 \mathrm{mM}$ arginine was added to perfusate in a second reservoir. Glucose concentrations greater than the baseline were attained with a sidearm syringe driven by syringe pump (Sage Instruments Div., Orion Research Inc., Cambridge, MA) which added $0.2 \mathrm{ml}$ to the usual flow rate of $3 \mathrm{ml} / \mathrm{min}$.

1. Abbreviations used in this paper: Px, $60 \%$ pancreatectomy; SUC, $10 \%$ sucrose water; WAT, tap water. 
Before delivery, the perfusate passed through an artificial lung to ensure adequate oxygenation (10). After cannulation of the aorta and portal vein, the body cavity was covered with gauze moistened with saline and placed under a heat lamp with the temperature being constantly monitored and maintained at $36-39^{\circ} \mathrm{C}$. All perfusions were preceded by a 20 -min period during which no samples were taken; thereafter, they were collected according to the protocols at the top of the respective figures for $30 \mathrm{~s}$ in chilled tubes that contained $4 \mathrm{mg}$ EDTA, and were kept on ice pending storage at $-20^{\circ} \mathrm{C}$.

Pancreatic extraction for insulin content. After study with the perfused pancreas, pancreases were removed, cleared of lymph nodes, blotted, weighed, and stored at $-20^{\circ} \mathrm{C}$ in acid ethanol. Later, on a single day, all were individually homogenized using an Ultra Turrax SDT (Tekmar Co., Cincinnati, $\mathrm{OH}$ ), diluted to a volume of $8 \mathrm{ml}$, and refrozen pending assay.

Quantitative morphometrics. At the end of $7 \mathrm{wk}$, pancreases were removed and cleared of fat and lymph nodes; shams were divided into two portions while Px were left whole. Each portion was weighed, placed in Bouin's fixative overnight, and embedded in paraffin. Sections (5-7 $\mu \mathrm{m})$ were stained by immunoperoxidase using a cocktail of antibodies against non-B islet endocrine cells, (non-B cells) that consisted of rabbit anti-synthetic somatostatin (our D-10), rabbit antibovine pancreatic polypeptide (gift of Dr. R. Chance, Eli Lilly, Indianapolis, IN), and rabbit anti-porcine glucagon (gift of Dr. M. Appel, University of Massachusetts Medical School, Worchester, MA). Control incubations that used excess antigen added to immune sera, nonimmune sera as primary antibody, and omission of the primary antibody, all resulted in the absence of hormone-specific staining. The relative volumes of the islet $B$ and non-B cells were quantified by the point counting method of Weibel (11): at a magnification of 350 starting at a random point in one corner of the slide, acinar and islet cells were scored in every other field using a 50-point grid, with a minimum of 5,000 points in 108 fields being counted per tissue block. Intercepts over blood vessels, fat, ducts, lymph nodes, and interlobular spaces were subtracted to give the total pancreatic counts. Islet $B$ and non-B cell masses were then calculated for each animal by multiplying the relative volumes times the pancreatic weight.

Analytical methods. Plasma glucose was measured with a glucose analyzer II (Beckman Instruments, Inc., Brea, CA). Insulin concentrations were determined using an RIA that employed charcoal separation (12) and rat insulin standards (gift of Dr. R. Chance, Eli Lilly, Indianapolis, IN).

Data presentation and statistical methods. The insulin concentrations of all samples collected during the perfused pancreas studies are depicted on the figures as single points with brackets that represent the mean and standard error (mean \pm SEM) for each group. The incremental insulin responses caused by $27.7 \mathrm{mM}$ glucose (taken from Figs. 2 and 3) are listed in Table III. They represent the total amount of insulin released above the secretory rate established at the end of the previous perfusate ( $2.8 \mathrm{mM}$ glucose), and they were calculated for each animal by subtracting the insulin concentration of the last sample at $2.8 \mathrm{mM}$ glucose from the mean of those taken during $27.7 \mathrm{mM}$ and multiplying by duration ( $15 \mathrm{~min}$ ) and flow rate. The mean \pm SEM for each group was then determined. The incremental response per milligram of B cells was calculated in the 6-wk groups by dividing these values by the B cell masses listed in Table II.

The incremental responses caused by arginine at 2.8 and $16.7 \mathrm{mM}$ glucose (Figs. 4 and 5) are listed in Table IV. The values at $2.8 \mathrm{mM}$ were calculated by subtracting the mean of the three samples taken at $2.8 \mathrm{mM}$ glucose alone from the mean insulin concentration of those collected during the arginine infusion and multiplying by duration ( 5 min) and flow rate. A similar method was used to calculate the values at $16.7 \mathrm{mM}$ glucose, except that the last sample taken before adding arginine was the only one used to establish the baseline. The incremental responses to arginine at $16.7 \mathrm{mM}$ glucose $/ \mathrm{mg}$ of B cells were calculated in the 6-wk groups by dividing each result by the B cell mass.

Statistical significance was determined using a one-way analysis of variance (13).

\section{Results}

General characteristics of the animal groups. Body weights and nonfasting plasma glucose and insulin values are listed in Table I. The sham-WAT rats tended to be slightly heavier than those of the other groups during much of the test period, but by the sixth week a difference could no longer be demonstrated. Plasma glucose and insulin values in Px-WAT remained equal to those of the sham-WAT group as they also did in the shams given sucrose, although there seemed to be a tendency for plasma insulin to increase in some. In contrast, Px-SUC rats were euglycemic during the first $25 \mathrm{~d}$ (samples were also obtained at 10 and $18 \mathrm{~d}$ but not included in Table I), but then developed mild hyperglycemia that was not associated with any change in plasma insulin.

The volume of fluid ingested per day averaged over weekly intervals is shown in Fig. 1. Sham and Px rats took in 40-50 ml

Table I. General Characteristics of Animal Groups

\begin{tabular}{|c|c|c|c|c|}
\hline & \multicolumn{2}{|c|}{ Sham } & \multicolumn{2}{|c|}{$\mathbf{P x}$} \\
\hline & Tap water & $10 \%$ sucrose & Tap water & $10 \%$ sucrose \\
\hline \multicolumn{5}{|c|}{ Body weight $(g)$} \\
\hline $25 \mathrm{~d}$ & $343 \pm 6(7)$ & $316 \pm 9(8)^{*}$ & $326 \pm 8(7)$ & $308 \pm 11(8)$ \\
\hline 4 wk & $369 \pm 7(7)$ & $346 \pm 12(8)$ & $346 \pm 7(7)^{*}$ & $345 \pm 12(8)$ \\
\hline $6 \mathrm{wk}$ & $408 \pm 10(12)$ & $421 \pm 12(14)$ & $427 \pm 9(12)$ & $391 \pm 12(12)$ \\
\hline \multicolumn{5}{|c|}{ Plasma glucose $(m g / d l)$} \\
\hline $25 \mathrm{~d}$ & $136 \pm 7(7)$ & $134 \pm 4(8)$ & $146 \pm 6(7)$ & $138 \pm 4(8)$ \\
\hline 4 wk & $139 \pm 3(7)$ & $140 \pm 7(8)$ & $141 \pm 3(7)$ & $154 \pm 4(8)^{*}$ \\
\hline $6 \mathrm{wk}$ & $149 \pm 4(9)$ & $148 \pm 5(10)$ & $150 \pm 3(8)$ & $166 \pm 6(10)^{*}$ \\
\hline \multicolumn{5}{|c|}{ Plasma insulin $(n g / m l)$} \\
\hline $25 \mathrm{~d}$ & $2.48 \pm 0.25(7)$ & $3.14 \pm 0.49(8)$ & $2.30 \pm 0.36(7)$ & $2.00 \pm 0.23(8)$ \\
\hline 4 wk & $2.03 \pm 0.20(7)$ & $3.37 \pm 0.70(8)$ & $2.13 \pm 0.26(7)$ & $2.15 \pm 0.11(8)$ \\
\hline $6 \mathrm{wk}$ & $2.03 \pm 0.43(9)$ & $2.81 \pm 0.90(10)$ & $1.63 \pm 0.28(9)$ & $1.89 \pm 0.35(11)$ \\
\hline
\end{tabular}

Results are expressed as mean \pm SEM. The values in parentheses are the number of samples measured. Statistical significance was determined using a one-way analysis of variance; all groups were compared with the sham rats given tap water. ${ }^{*} P<0.05$. 


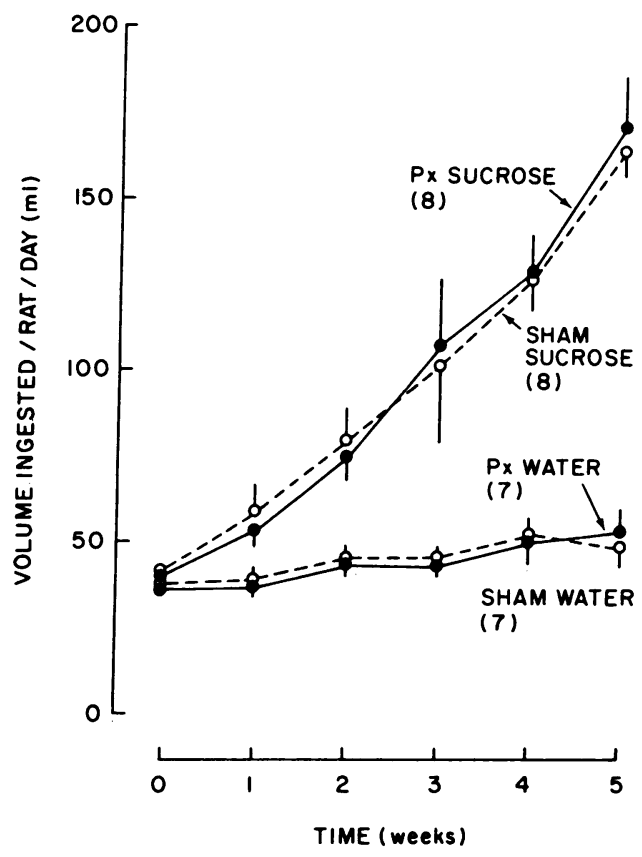

Figure 1. Volume of fluid ingested per day averaged over weekly intervals.

of tap water which did not appreciably change over the test period even though body weight nearly tripled. In contrast, both sucrose groups consumed equal volumes that progressively increased to $\sim 150 \mathrm{ml} / \mathrm{d}$.

Islet morphometrics and pancreatic insulin content. B cell mass in Px-WAT averaged 55\% of that in shams and non-B cell mass was $43 \%$ (Table II). Pancreatic weight and insulin content were similarly reduced which resulted in identical amounts of stored insulin per milligram of B cells in the two tap water groups $(12.8 \pm 1.1 \mu \mathrm{g} / \mathrm{mg}$ B cells in Px-WAT vs. $13.4 \pm 0.8$ in sham-WAT).

Sucrose did not significantly alter any of these parameters in shams. In contrast, B and non-B cell masses in Px markedly increased, reaching values close to those of both sham groups. On the other hand, pancreatic content was unchanged so that the amount of insulin stored per milligram of B cells was less than the other groups (7.1 $\pm 0.5 \mu \mathrm{g} / \mathrm{mg} \mathrm{B}$ cells).

Insulin responses to varying glucose concentrations assessed with the in vitro perfused pancreas. The perfusion protocol is shown at the top of Figs. 2 and 3. The baseline perfus- ate contained $7.8 \mathrm{mM}$ glucose which was decreased to $2.8 \mathrm{mM}$ for $10 \mathrm{~min}$ and increased to $27.7 \mathrm{mM}$ for $15 \mathrm{~min}$. Results obtained after 4 wk are shown in Fig. 2 while those after 6 wk are in Fig. 3.

As expected, in shams given tap water for $4 \mathbf{w k}$, insulin release was fully suppressed during $2.8 \mathrm{mM}$ glucose and was followed by a marked biphasic response to $27.7 \mathrm{mM}$ (Fig. 2). The results in the sham-SUC group were very similar. In contrast, the insulin levels attained during the high glucose perfusate in Px-WAT were considerably less resulting in a $50 \%$ reduction in the incremental response $(410 \pm 53 \mathrm{ng}$ in Px-WAT vs. $741 \pm 114$ in sham-WAT, $P<0.03$ ). Identical results were found in Px-SUC.

When studied after $6 \mathrm{wk}$, insulin secretion in the two sham groups was again stimulated equally by $27.7 \mathrm{mM}$ glucose (Table III), and the response was again reduced by $50 \%$ in Px-WAT. However, this time, an even further decrease was found in Px-SUC (280 $\pm 56 \mathrm{ng}$ in Px-SUC vs. $538 \pm 69$ in PxWAT, $P<0.02$ ) so that the incremental response per milligram of B cells was considerably less than that found in the other groups $(31 \pm 6 \mathrm{ng} / \mathrm{mg}$ B cells Px-SUC, 101 \pm 13 Px-WAT, $123 \pm 17$ sham-WAT, $123 \pm 11$ sham-SUC).

Glucose potentiation of arginine-induced insulin secretion assessed with the perfused pancreas. The perfusion protocol is shown at the top of Figs. 4 and $5.10 \mathrm{mM}$ arginine was added for $5 \mathrm{~min}$ to the baseline perfusate that contained $2.8 \mathrm{mM}$ glucose. After reequilibration at $2.8 \mathrm{mM}$ glucose, the glucose concentration was increased to $16.7 \mathrm{mM}$ and arginine was added again. Results were obtained after 4 (Fig. 4) and 6 (Fig. 5) wk.

As expected, in the shams studied after 4 wk of tap water, the insulin response to arginine at the high glucose background far exceeded that found at a low glucose background (Fig. 4). When given sucrose, arginine-induced release at $2.8 \mathrm{mM}$ glucose was unchanged while that at $16.7 \mathrm{mM}$ more than doubled (Table IV). In both Px groups, results were similar to the sham-WAT rats.

At the end of the 6-wk test period, the two sham groups now had very similar results (Fig. 5). In both Px groups, arginine-induced insulin secretion at $2.8 \mathrm{mM}$ glucose was similar to that of the shams (Table IV); in contrast, the response at the high glucose background was reduced by $50 \%$ in Px-WAT and even a little more in Px-SUC, although the incremental values were not statistically different (384 $\pm 72 \mathrm{ng}$ in Px-WAT vs. $247 \pm 49$ in Px-SUC, $P=$ NS). When expressed per milligram of $B$ cells, the insulin response caused by arginine at $16.7 \mathrm{mM}$

Table II. Islet Morphometric Results and Pancreatic Insulin Content

\begin{tabular}{|c|c|c|c|c|}
\hline & \multicolumn{2}{|c|}{ Sham } & \multicolumn{2}{|c|}{$\mathbf{P x}$} \\
\hline & Tap water & $10 \%$ sucrose & Tap water & $10 \%$ sucrose \\
\hline B cell mass $(m g)$ & $9.65 \pm 0.73(6)$ & $10.8 \pm 0.60(6)$ & $5.32 \pm 0.44(6)^{*}$ & $8.99 \pm 1.66(6)$ \\
\hline Non-B cell mass $(m g)$ & $3.72 \pm 0.23(6)$ & $3.90 \pm 0.05(6)$ & $1.67 \pm 0.18(6)^{*}$ & $3.19 \pm 0.64(6)$ \\
\hline Pancreas weight $(g)$ & $1.39 \pm 0.07(6)$ & $1.28 \pm 0.08(6)$ & $0.70 \pm 0.03(6)^{*}$ & $0.69 \pm 0.03(6)^{*}$ \\
\hline Insulin content $(\mu g)$ & $129 \pm 7.8(9)$ & $127 \pm 10(10)$ & $67.9 \pm 5.7(8)^{*}$ & $64.1 \pm 4.1(10)^{*}$ \\
\hline
\end{tabular}

Results are expressed as mean \pm SEM. The values in parentheses are the number of samples measured. B and non-B cell masses were measured using point-counting morphometrics. Insulin content was measured in other pancreases obtained after the perfused pancreas studies. Statistical significance was determined using a one-way apalysis of variance; all groups were compared with the sham rats given tap water. ${ }^{*} P<0.05$. 


\begin{tabular}{|l|l|l|}
\hline 7.8 & 2.8 & $27.7 \mathrm{mM}$ GLUCOSE \\
\hline
\end{tabular}

\begin{tabular}{|l|l|l|}
\hline 7.8 & 2.8 & $27.7 \mathrm{mM}$ GLUCOSE \\
\hline
\end{tabular}
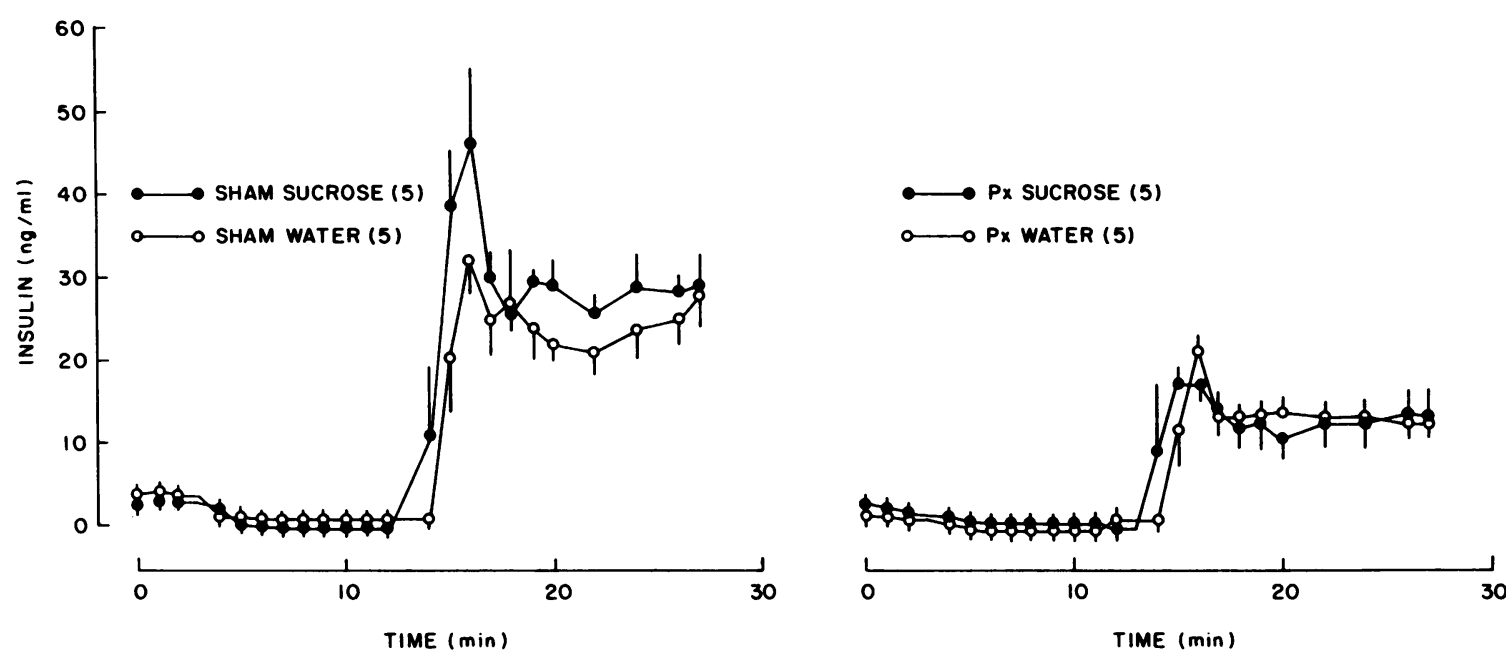

Figure 2. Effects of an acute reduction and then increase in perfusate glucose concentration on insulin secretion. Rats underwent a Px at 5 wk of age or were sham-operated, and then were given tap water or $10 \%$ sucrose ad lib. for 4 wk.

glucose in Px-WAT was equal to the response in the sham groups $(72 \pm 14 \mathrm{ng} / \mathrm{mg}$ B cells Px-WAT, $81 \pm 20$ sham-WAT, $60 \pm 8$ sham-SUC), but it was reduced in Px-SUC $(27 \pm 5 \mathrm{ng} / \mathrm{mg}$ B cells, $P<0.0007$ vs. Px-WAT).

\section{Discussion}

The results of this study do not show any long-term effects of the $60 \%$ pancreatectomy itself that alters the function of the remaining B cells: pancreatic insulin content in Px-WAT was reduced in proportion with the B cell loss as were the insulin responses to $27.7 \mathrm{mM}$ glucose and to arginine when given at the high glucose background. This contrasts with a $90 \%$ pancreatectomy where glucose-induced insulin secretion is virtually absent in the face of a B cell mass that (because of regeneration) averages $40 \%$ of that in controls (8). Unlike a $60 \%$ pancreatectomy, the $90 \%$ model develops hyperglycemia with the nonfasting plasma glucose concentration increasing $40 \mathrm{mg} / \mathrm{dl}$, and we have proposed that chronic exposure to this increase is what causes the B cell secretory abnormalities $(1,8)$.

The present results strongly support this concept, for the addition of sucrose to the water supply caused mild hyperglycemia in Px, and this was associated with a decrease in the insulin response to $27.7 \mathrm{mM}$ glucose, even though pancreatic

\begin{tabular}{|l|l|l|}
\hline 7.8 & 2.8 & $27.7 \mathrm{mM}$ GLUCOSE \\
\hline
\end{tabular}

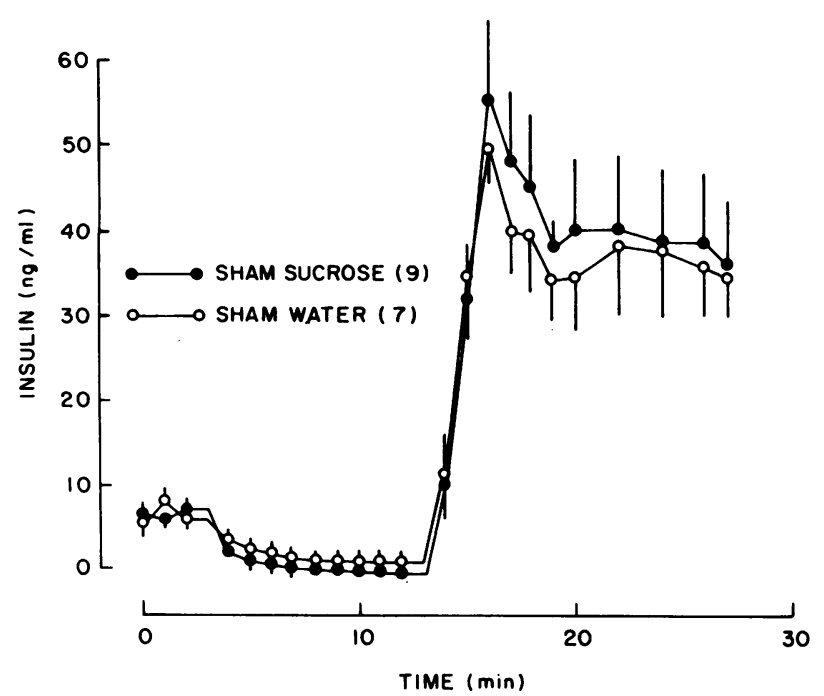

\begin{tabular}{|l|l|l|}
\hline 7.8 & 2.8 & $27.7 \mathrm{mM}$ GLUCOSE \\
\hline
\end{tabular}

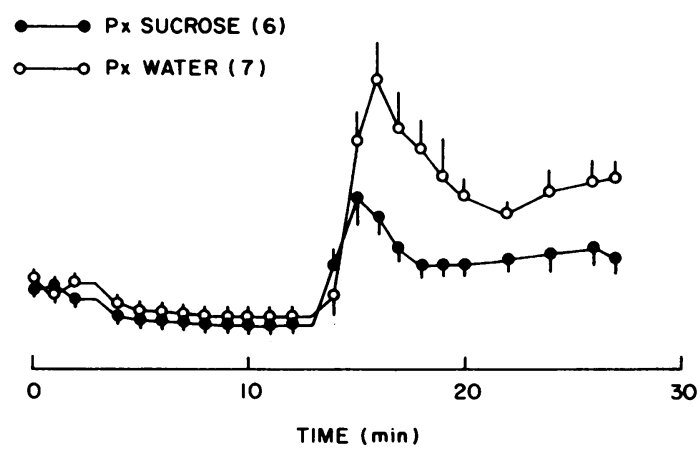

Figure 3. Effects of an acute reduction and then increase in perfusate glucose concentration on insulin secretion. Rats underwent a Px at 5 wk of age or were sham-operated, and then they were given tap water or $10 \%$ sucrose ad lib. for $6 \mathrm{wk}$. 


\begin{tabular}{|c|c|c|c|}
\hline & \multicolumn{3}{|c|}{ Insulin release } \\
\hline & $2.8 \mathrm{mM}$ glucose & $\begin{array}{l}\text { Incremental response } \\
27.7 \mathrm{mM} \text { glucose }\end{array}$ & $\begin{array}{c}\text { Incremental response } \\
27.7 \mathrm{mM} \text { glucose/ } \\
\mathrm{mg} \mathrm{B} \text { cells }\end{array}$ \\
\hline & $n g / \min$ & $\mathrm{ng} / 15 \mathrm{~min}$ & $\mathrm{ng} / 15 \mathrm{~min}$ \\
\hline \multicolumn{4}{|l|}{$4 \mathrm{wk}$} \\
\hline Sham tap water (5) & $0.54 \pm 0.27$ & $741 \pm 114$ & \\
\hline Sham $10 \%$ sucrose $(5)$ & $0.30 \pm 0.03$ & $913 \pm 76$ & \\
\hline Px tap water (5) & $0.40 \pm 0.13$ & $410 \pm 53^{*}$ & \\
\hline Px $10 \%$ sucrose (5) & $0.36 \pm 0.09$ & $395 \pm 74^{*}$ & \\
\hline \multicolumn{4}{|l|}{$6 \mathrm{wk}$} \\
\hline Sham tap water (7) & $0.60 \pm 0.15$ & $1,190 \pm 162$ & $123 \pm 17$ \\
\hline Sham $10 \%$ sucrose (9) & $0.42 \pm 0.10$ & $1,330 \pm 221$ & $123 \pm 11$ \\
\hline Px tap water (7) & $0.54 \pm 0.29$ & $538 \pm 69^{*}$ & $101 \pm 13$ \\
\hline Px $10 \%$ sucrose (6) & $0.52 \pm 0.30$ & $280 \pm 56^{*}$ & $31 \pm 6^{*}$ \\
\hline
\end{tabular}

Insulin release is expressed as mean $\pm \mathrm{SEM}$. The value at $2.8 \mathrm{mM}$ glucose is the amount released during the last minute of that perfusate. The incremental response to $27.7 \mathrm{mM}$ is the amount released above that baseline during the 15 -min infusion period; see text for details. Statistical significance was determined using a one-way analysis of variance; all results were compared with the sham rats given tap water. ${ }^{*} P<0.05$.

content was unchanged and B cell mass nearly doubled. Also, the ability of glucose to potentiate arginine-induced insulin secretion was markedly reduced when B cell mass was taken into account. One might wonder if a dietary change and not hyperglycemia caused the secretory defects. Although we did not measure how much chow was consumed by the different groups, others have shown using similar systems in normal rats that it is reduced by a third while total calorie intake is $20 \%$ higher $(14,15)$, which results in an overall decrease in protein and fat intake while carbohydrate intake is increased. It has been clearly demonstrated that a low protein-hypocaloric diet tends to depress insulin secretion $(16,17)$, but when carbohydrate is added to make up the missing calories, secretory responses are unchanged (18). High sucrose diets have also been shown by some investigators to decrease glucose tolerance in normal rats (19-21), but this remains controversial (22-24). More germane to our results, a recent study failed to find any decrease in glucose-induced insulin secretion assessed with the perfused pancreas when normal rats were given a high sucrose diet for a month (25). The most compelling evidence against diet being the cause of the secretory defects in PX-SUC comes from the sham-SUC group; insulin responses remained fully intact despite identical intake of sucrose.

Therefore, we suggest that chronic exposure of the remaining B cells to the higher than normal plasma glucose concentration is what caused the secretory defects. A large body of literature already supports the notion that chronic hyperglycemia impairs B cell function $(1,2,26)$; this study is noteworthy because it shows that a very small change in glucose homeostasis also has this effect (nonfasting plasma glucose level was

\begin{tabular}{|l|l|l|}
\hline \multicolumn{2}{|c|}{$2.8 \mathrm{mM}$} & $16.7 \mathrm{mM}$ GLUCOSE \\
\hline ARG & ARG \\
\hline
\end{tabular}
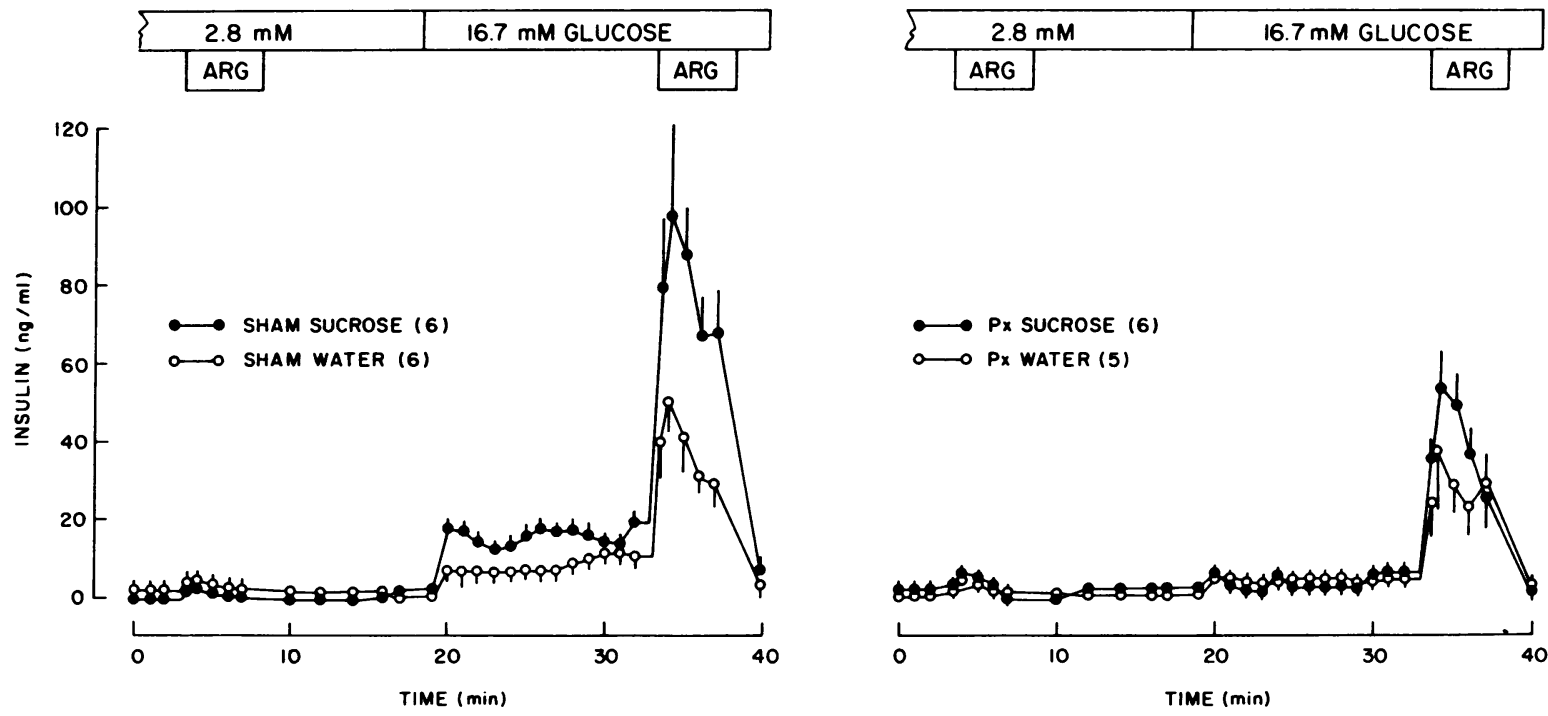

Figure 4. Effects of glucose and $10 \mathrm{mM}$ arginine on insulin secretion. Rats underwent a Px at 5 wk of age or were sham-operated, and then they were given tap water or $10 \%$ sucrose ad lib. for 4 wk. 


\begin{tabular}{|l|l|l|}
\hline \multicolumn{2}{|c|}{$2.8 \mathrm{mM}$} & $16.7 \mathrm{mM}$ GLUCOSE \\
\hline ARG & ARG \\
\hline
\end{tabular}

\begin{tabular}{|l|l|l|}
\hline \multicolumn{2}{|c|}{$2.8 \mathrm{mM}$} & $16.7 \mathrm{mM}$ GLUCOSE \\
\hline ARG & ARG \\
\hline
\end{tabular}
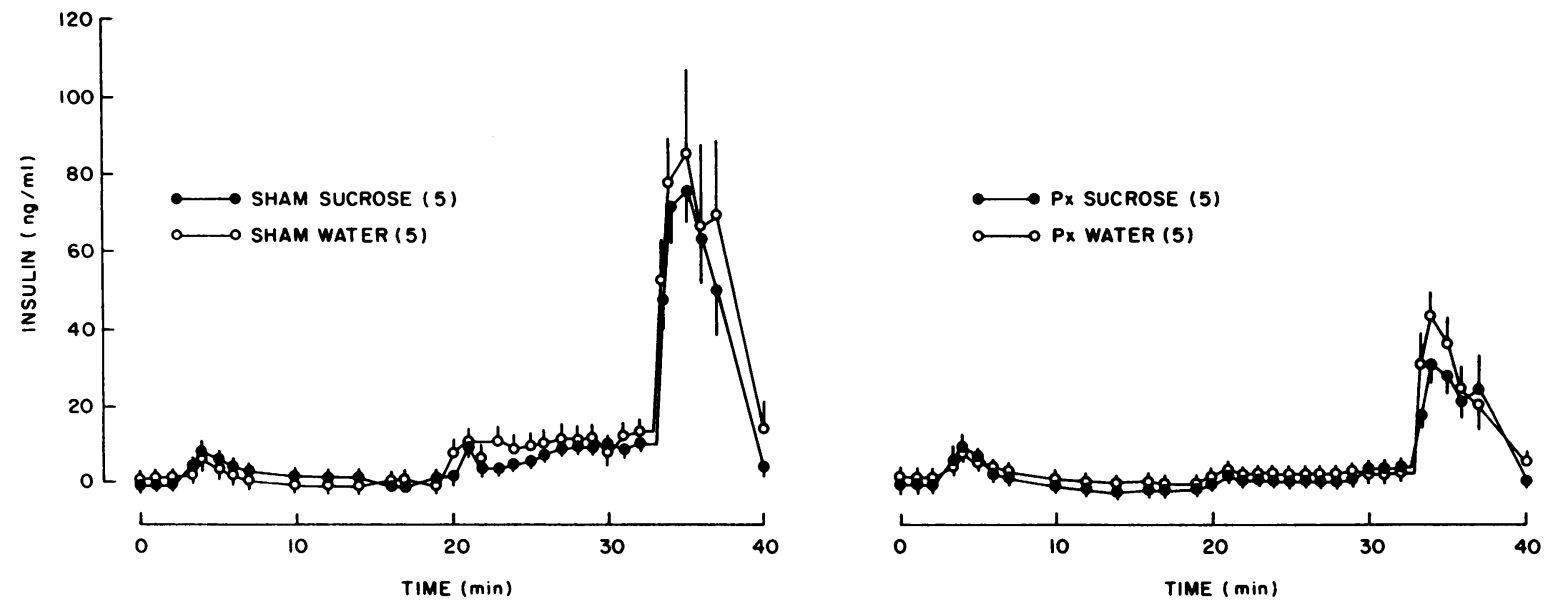

Figure 5. Effects of glucose and $10 \mathrm{mM}$ arginine on insulin secretion. Rats underwent a Px at 5 wk of age or were sham-operated, and then they were given tap water or $10 \%$ sucrose ad lib. for 6 wk.

raised only $15 \mathrm{mg} / \mathrm{dl}$ ). We have previously observed in rats given streptozotocin as neonates that glucose-induced insulin secretion was lost at a time when their glucose level was only slightly elevated (27). However, an attempt to establish a link between the two, using 48-h in vivo glucose infusions in normal rats, was not successful; rats whose plasma glucose was raised $18 \mathrm{mg} / \mathrm{dl}$ had no loss of glucose-induced insulin secretion while it was markedly blunted in those who were made more hyperglycemic (2). One explanation could be that it requires a longer period for functional abnormalities to evolve when hyperglycemia is very mild. Possibly consistent with this suggestion is the fact that the insulin responses to $27.7 \mathrm{mM}$ glucose in the Px groups were not different at the end of the 4th wk, a time when hyperglycemia was already well established (plasma glucose levels obtained at the beginning of the perfusion surgery showed the expected $15 \mathrm{mg} / \mathrm{dl}$ increase), but marked differences were found $2 \mathrm{wk}$ later.

It has been hypothesized that sustained hyperglycemia has another effect on the islet, namely to accelerate islet growth by increasing the number of cells undergoing mitosis (1). This is based on the fact that glucose is a well-known stimulus for in vitro B cell replication (28), and also because considerable B and non-B cell regeneration has been observed after a $90 \%$ pancreatectomy (8) that was associated with a marked increase

Table IV. Insulin Responses to $10 \mathrm{mM}$ Arginine Given at 2.8 and $16.7 \mathrm{mM}$ Glucose Assessed with the In Vitro Perfused Pancreas

\begin{tabular}{|c|c|c|c|}
\hline & \multicolumn{3}{|c|}{ Insulin release } \\
\hline & $\begin{array}{c}\text { Incremental response: } \\
10 \mathrm{mM} \text { arginine } \\
+2.8 \mathrm{mM} \text { glucose }\end{array}$ & $\begin{array}{l}\text { Incremental response: } \\
10 \mathrm{mM} \text { arginine } \\
+16.7 \mathrm{mM} \text { glucose }\end{array}$ & $\begin{array}{c}\text { Incremental response: } \\
10 \mathrm{mM} \text { arginine } \\
+16.7 \mathrm{mM} \text { glucose/ } \\
\text { mg B cells }\end{array}$ \\
\hline & $\mathrm{ng} / 5 \mathrm{~min}$ & $n g / 5 \min$ & $n g / 5 \min$ \\
\hline \multicolumn{4}{|l|}{$4 \mathrm{wk}$} \\
\hline Sham tap water (6) & $19.2 \pm 5.0$ & $355 \pm 57$ & \\
\hline Sham $10 \%$ sucrose $(6)$ & $11.9 \pm 3.7$ & $740 \pm 143^{*}$ & \\
\hline Px tap water (5) & $19.7 \pm 12.1$ & $307 \pm 88$ & \\
\hline Px 10\% sucrose (6) & $20.7 \pm 3.1$ & $406 \pm 77$ & \\
\hline \multicolumn{4}{|l|}{$6 \mathrm{wk}$} \\
\hline Sham tap water (5) & $34.7 \pm 14.1$ & $786 \pm 196$ & $81 \pm 20$ \\
\hline Sham $10 \%$ sucrose $(5)$ & $65.4 \pm 12.0$ & $649 \pm 85$ & $60 \pm 8$ \\
\hline Px tap water (5) & $53.0 \pm 11.2$ & $384 \pm 72$ & $72 \pm 14$ \\
\hline Px 10\% sucrose (5) & $50.4 \pm 18.5$ & $247 \pm 49^{*}$ & $27 \pm 6^{*}$ \\
\hline
\end{tabular}

Insulin release is expressed as mean $\pm \mathrm{SEM}$. The incremental responses are the total amount of insulin released above the baseline established at the end of the 2.8 or $16.7 \mathrm{mM}$ glucose perfusates; see text for the method of calculation. Statistical significance was determined using a one-way analysis of variance; all results were compared with the sham rats given tap water. ${ }^{*} P<0.05$. 
in B cell mitotic frequency (non-B cell mitotic frequency cannot be measured with the same technique due to the smaller populations of cells) (29). Even more direct evidence has recently been obtained, for we have found a $50 \%$ increase in B cell mass when normal rats are made markedly hyperglycemic for $96 \mathrm{~h}$ with in vivo glucose infusions (30). The present results further support this concept, showing B and non-B cell masses in Px-SUC that were considerably increased over Px-WAT. On the other hand, it is likely that other factors also influence islet-cell growth after a partial pancreatectomy, for we have observed a $20 \%$ increase in islet mass $3 \mathrm{wk}$ after a $40 \%$ pancreatectomy, despite there being no change in glucose homeostasis (Lee, H. C., J. L. Leahy, S. Bonner-Weir, and G. C. Weir, manuscript submitted for publication). Consistent with this possibility, B cell mass in Px-WAT was 55\% of that in shams instead of the expected $40 \%$.

In contrast to the marked B cell regeneration in Px-SUC, insulin content did not increase, which resulted in less stored insulin per milligram of B cells. Although the mechanism for this is unknown, it may reflect an inhibitory effect of hyperglycemia on insulin synthesis (31), although there is some question as to whether such an effect always occurs (32).

In summary, we have described experiments that allow study of the consequences of a reduction in B cell mass alone, and those that result from superimposed, very mild hyperglycemia. When islet mass is reduced to a level that does not cause hyperglycemia, some regeneration occurs and the function of the remaining B cells remains fully intact. Therefore, insulin content is reduced in proportion to the B cell loss as is the amount of insulin released to a marked stimulus. In contrast, if even very mild hyperglycemia develops, islet growth increases with further regeneration of both $B$ and non-B cells. However, B cell function eventually becomes impaired as characterized by secretory defects and reduced insulin stores. Then, the absolute amount of insulin released to a marked stimulus depends upon the balance between how much B cell mass has grown vs. the severity of the B cell defects. For instance, the ability of $16.7 \mathrm{mM}$ glucose to potentiate arginine-induced insulin secretion in the 6-wk Px groups was not different when viewed in absolute terms, but it was inappropriately low in Px-SUC when B cell mass was taken into account. It has been suggested that the ability of a high glucose concentration to potentiate arginine-induced insulin secretion directly depends upon B cell mass and that its measurement can be used clinically to detect subtle degrees of B cell damage $(33,34)$. Our results are in agreement with this, but only in the absence of hyperglycemia.

These results provide further evidence that mild chronic hyperglycemia resulting from a reduced B cell mass is a critical determinant of impaired B cell function. This concept may be germane to all forms of diabetes. The most analogous situation is insulin-dependent diabetes mellitus in which it has been found that glucose-induced insulin secretion is impaired even in the very early stages when hyperglycemia is not obvious (35, 36). At this point in the evolution of insulin-dependent diabetes mellitus, $B$ cell mass is presumed to be reduced and the plasma glucose levels are considerably below those required for the diagnosis of diabetes. Although unproven, one must suspect that the glucose levels in these individuals are increased enough to initiate and maintain abnormal B cell function. The pathophysiology is more obvious in non-insulin-de- pendent diabetes mellitus, where a growing body of evidence supports the concept that chronic hyperglycemia, even if very mild, is responsible for the observed secretory defects $(1,3,4)$.

\section{Acknowledgments}

The authors wish to thank Henrietta Cooper and Deanna Deery for expert technical assistance.

The work was supported by grants AM-35449 and AM-38543 from the National Institutes of Health and 185296 from the Juvenile Diabetes Foundation. Dr. Leahy is the recipient of a Research and Development Award from the American Diabetes Association.

\section{References}

1. Weir, G. C., J. L. Leahy, and S. Bonner-Weir. 1986. Experimental reduction of B-cell mass: implications for the pathogenesis of diabetes. Diabetes Metab. Rev. 2:125-161.

2. Leahy, J. L., H. E. Cooper, D. A. Deal, and G. C. Weir. 1986. Chronic hyperglycemia is associated with impaired glucose influence on insulin secretion. A study in normal rats using chronic in vivo glucose infusions. J. Clin. Invest. 77:908-915.

3. Weir, G. C. 1982. Non-insulin-dependent diabetes mellitus: interplay between B-cell inadequacy and insulin resistance. $\mathrm{Am}$. J. Med. 13:461-464.

4. Unger, R. H., and S. Grundy. 1985. Hyperglycemia as an inducer as well as a consequence of impaired islet function and insulin resistance: implications for the management of diabetes. Diabetologia. 28:119-121.

5. Cerasi, E., R. Luft, and S. Efendic. 1972. Decreased sensitivity of the pancreatic beta cell to glucose in prediabetic and diabetic subjects. A glucose dose response study. Diabetes. 21:224-234.

6. Brunzell, J. D., R. P. Robertson, R. L. Lerner, W. R. Hazzard, J. W. Ensinck, E. L. Bierman, and D. Porte, Jr. 1976. Relationships between fasting plasma glucose levels and insulin secretion during intravenous glucose tolerance tests. J. Clin. Endocrinol. \& Metab. 42:222-229.

7. Foglia, V. G. 1944. Characteristicas de la diabetes en la rata. Rev. Soc. Argent. Biol. 20:21-37.

8. Bonner-Weir, S., D. F. Trent, and G. C. Weir. 1983. Partial pancreatectomy in the rat and subsequent defect in glucose-induced insulin release. J. Clin. Invest. 71:1544-1553.

9. Weir, G. C., S. D. Knowlton, and D. B. Martin. 1974. Glucagon secretion from the perfused rat pancreas. Studies with glucose and catecholamines. J. Clin. Invest. 54:1403-1412.

10. Hamilton, R. L., M. N. Berry, M. C. Williams, and E. M. Severinghaus. 1974. A simple and inexpensive membrane "lung" for small organ perfusion. J. Lipid Res. 15:182-186.

11. Weibel, E. R. 1963. Principles and methods for the morphometric studies of the lung and other organs. Lab. Invest. 12:131-155.

12. Albano, J. D. M., R. P. Ekins, G. Maritz, and R. C. Turner. 1972. A sensitive, precise radioimmunoassay of serum insulin relying on charcoal separation of bound and free hormone moieties. Acta Endocrinol. 70:487-509.

13. Snedecor, G. W., and W. G. Cochran. 1967. Statistical Methods. Iowa State University Press, Ames, IA. 1-593.

14. Collier, G., and R. Bolles. 1968. Some determinants of intake of sucrose solutions. J. Comp. Physiol. Psychol. 65:379-383.

15. Kanarek, R. B., and E. Hirsch. 1977. Dietary-induced overeating in experimental animals. Fed. Proc. 36:154-158.

16. Levine, L. S., P. G. Wright, and F. Marcus. 1983. Failure to secrete immunoreactive insulin by rats fed a low protein diet. Acta Endocrinol. 102:240-245.

17. Swenne, I., C. J. Crace, and R. D. G. Milner. 1987. Persistent impairment of the insulin secretory response to glucose in adult rats 
after limited period of protein-calorie malnutrition early in life. Diabetes. 36:454-458.

18. Rossetti, L., D. Rothman, and G. Shulman. 1987. Effect of protein and carbohydrate intake on insulin action and hepatic glycogen synthesis. Diabetes. 36(Suppl. 1):37A. (Abstr.)

19. Cohen, A. M., and A. Tietelbaum. 1964. Effect of dietary sucrose and starch on oral glucose tolerance and insulin-like activity. Am. J. Physiol. 206:105-108.

20. Laube, H., H. Schatz, C. Nierle, R. Fussgänger, and E. F. Pfeiffer. 1976. Insulin secretion and biosynthesis in sucrose fed rats. Diabetologia. 12:441-446.

21. Hallfrisch, J., F. L. Lazar, C. Jorgensen, and S. Reiser. 1979. Insulin and glucose responses in rats fed sucrose or starch. Am. J. Clin. Nutr. 32:787-793.

22. Lin, W., and J. W. Anderson. 1977. Effects of high sucrose or starch bran diets on glucose and lipid metabolism of normal and diabetic rats. J. Nutr. 107:584-595.

23. Portha, B., M. H. Giroix, and L. Picon. 1982. Effect of diet on glucose tolerance and insulin response in chemically diabetic rats. Metab. Clin. Exp. 21:1194-1199.

24. Vallerand, E. L., J. Lupien, and L. J. Bukowiecki. 1986. Synergistic improvement of glucose tolerance by sucrose feeding and exercise training. Am. J. Physiol. 250:E607-E614.

25. Kergoat, M., D., Bailbé, and B. Portha. 1987. Effect of high sucrose diet on insulin secretion and insulin action: a study in the normal rat. Diabetologia. 30:252-258.

26. DeFronzo, R. A., and L. Rossetti. 1987. Effect of chronic hyperglycemia on in vivo insulin secretion in partially pancreatectomized rats. Diabetes. 36(Suppl. 1):44A. (Abstr.)

27. Trent, D. F., D. J. Fletcher, J. M. May, S. Bonner-Weir, and G. C. Weir. 1984. Abnormal islet and adipocyte function in young B-cell-deficient rats with near-normoglycemia. Diabetes. 33:170-175.
28. Chick, W. L. 1973. Beta cell replication in rat pancreatic monolayer cultures: effects of glucose, tolbutamide, glucocorticoid, growth hormone and glucagon. Diabetes. 22:687-693.

29. Brockenbrough, J. S., G. C. Weir, and S. Bonner-Weir. 1988. Discordance of exocrine and endocrine growth following $90 \%$ partial pancreatectomy in the rat. Diabetes. 37:232-236.

30. Bonner-Weir, S., and D. Deery. 1987. Selective growth of adult B-cells is seen during short term in vivo glucose infusions. Diabetes. 36(Suppl. 1):6A. (Abstr.)

31. Orland, M. J., R. Chyn, and M. A. Permutt. 1985. Modulation of proinsulin messenger RNA after partial pancreatectomy in rats. Relationship to glucose homeostasis. J. Clin. Invest. 75:2047-2055.

32. Halban, P. A., S. Bonner-Weir, and G. C. Weir. 1983. Elevated proinsulin biosynthesis in vitro from a rat model of non-insulin-dependent diabetes mellitus. Diabetes. 32:277-283.

33. McCulloch, D. K., P. K. Raghu, L. J. Klaff, D. J. Koerker, and J. P. Palmer. 1985. Impaired glucose potentiation of arginine stimulated insulin release is a sensitive and reliable marker of B-cell damage. Diabetes. 34(Suppl. 1):85A. (Abstr.)

34. Ward, W. K., G. J. Taborsky, and J. C. Beard. 1986. Reduced maximal potentiation of the insulin response to arginine: a sensitive indicator of B-cell damage. Diabetes. 35(Suppl. 1):98A. (Abstr.)

35. Srikanta, S., O. P. Ganda, R. A. Jackson, R. E. Gleason, A. Kaldany, M. R. Garovoy, E. L. Milford, C. B. Carpenter, J. S. Soeldner, and G. S. Eisenbarth. 1983. Type 1 Diabetes Mellitus in monozygotic twins: progressive beta cell dysfunction. Ann. Intern. Med. 99:320-326.

36. Ganda, O. P., S. Srikanta, S. J. Brink, M. A. Morris, R. A. Gleason, J. S. Soeldner, and G. S. Eisenbarth. 1984. Differential sensitivity to B-cell secretagogues in "early," type 1 diabetes mellitus. Diabetes. 33:516-521. 